\title{
Corporate Governance and Financial Reporting Quality: The Case of Tunisian Firms
}

\author{
Nesrine Klai (Corresponding author) \\ Institut Supérieur de Gestion de Tunis, University of Tunis \\ 41, Avenue de la Liberté, Cité Bouchoucha, 2000, Bardo, Tunisia \\ Corresponding address: 14 Rue Aziz Tej, Mourouj 1, Ben Arous, 2074, Tunisia \\ Tel: 21-69-864-6955 E-mail: nesrine_klai@yahoo.fr \\ Abdelwahed Omri \\ Institut Supérieur de Gestion de Tunis, University of Tunis \\ 41, Avenue de la Liberté, Cité Bouchoucha, 2000, Bardo, Tunisia \\ E-mail: abomri@yahoo.fr
}

\begin{abstract}
The proliferation of accounting scandals has prompted the need to improve the relevance of financial reporting by setting up good governance structures. The relationship between corporate governance and information quality has been strongly debated in the context of developed countries. It is only recently that attention turned to the study of governance and financial disclosure in emerging countries.

In this paper, we examine the effect of the governance mechanisms on the financial reporting quality for a sample of Tunisian firms. Specifically, we focus on the characteristics of the board of directors and the ownership structure of the firms listed on the Tunis Stock Exchange during the period 1997-2007. The results reveal that the governance mechanisms affect the financial information quality of the Tunisian companies. Particularly, the power of the foreigners, the families and the blockholders reduces the reporting quality, while the control by the State and the financial institutions is associated with a good quality of financial disclosure.
\end{abstract}

Keywords: Corporate governance, Board of directors, Corporate ownership, Financial information quality, Tunisian firms

\section{Introduction}

The wave of accounting scandals occurred recently in the international financial community has raised many criticisms about the financial reporting quality (Agrawal and Chadha, 2005; Brown et al., 2010). Several prominent companies were involved in accounting frauds, such as Enron, WorldCom, Marconi, Parmalat, etc, which has weakened the investor confidence toward the management team and the financial reports. The widespread failure in the financial disclosure has created the need to improve the financial information quality and to strengthen the control of managers by setting up good governance structures (Karamaou and Vafeas, 2005; Beekes and Brown, 2006; Brown and Caylor, 2006; Firth et al., 2007; Petra, 2007). Indeed, the financial information serves as a basis for investment decisions of the capital market participants. It is useful for owners, creditors, firm partners and regulators, since it helps to determine the firm's past performance, predict its future profitability and monitor the managers' actions (Bushman and Smith, 2001; 2003).

The link between corporate governance and financial information quality has been strongly discussed in the developed countries. Emphasis was placed on specific governance mechanisms such as concentrated shareholding (Yeo et al., 2002; Han, 2005), board independence (Beekes et al., 2004; Bradbury et al., 2006; Petra, 2007), director shareholding (Ballesta and Meca, 2007) and auditor reputation (Agrawal and Chadha, 2005). Recently, attention turned to the study of corporate governance and financial reporting in the emerging economies which are rapidly growing and have distinctive features about corporate control, capital allocation and regulations (Bradbury et al., 2006; Firth et al., 2007; Dimitropoulos and Asteriou, 2010).

In this paper, we study the governance features and the financial reporting in the Tunisian context. Specifically, we empirically investigate the impact of the governance mechanisms on the financial information quality of the Tunisian listed firms. This question is relevant to examine because the Tunisian market is more and more expanding. It adopted several reform programs to modernize the financial market, promote the foreign investment, privatize the public firms and liberalize the trade. Although the concept of corporate governance is still at an embryonic stage, the 
Tunisian regulators emphasized the necessity of disclosing relevant and reliable information by the listed firms. Hence, we posit in our study that the governance mechanisms affect the quality of financial reporting of the Tunisian companies.

Using a panel of 22 non financial firms listed on the Tunis Stock Exchange during the period 1997-2007, our results confirm the link between corporate governance and financial information quality. Particularly, we find that the control by the State and the financial institutions is associated with a good quality of financial reporting. However, we discern that the presence of the blockholders, the families and the foreigners in the Tunisian firms reduces the information content of incomes and enhances the earnings management.

Our research contributes to the extant literature in three ways. First, we investigate the relationship between corporate governance and financial reporting quality in an emerging market which is Tunisia. Second, we identify the control mechanisms which are specific to the Tunisian firms. Principally, we focus on the identity of directors and shareholders to identify the principal governance mechanisms. Third, we assess the quality of financial information by combining an accounting and a market based measures into one factor, in order to have a relevant measure of financial reporting quality for the Tunisian companies.

The reminder of this paper is organized as follows. In the second section, we discuss the literature review about the link between corporate governance and financial information quality. In the third section, we expose the methodological approach and in the forth section, we present the main results of our empirical investigation. In the fifth section, we provide concluding remarks.

\section{Governance mechanisms and financial information quality}

In this paper, we are interested in the governance mechanisms that can influence the quality of financial information. Particularly, we focus on the characteristics of the board of directors and the ownership structure, as well as the reputation of the external auditor. In what follows, we provide a survey of the theoretical and empirical literature about the link between corporate governance and financial information quality.

First, the emphasis was placed on the composition of the board of directors. Beasley (1996) argued that the probability of detecting financial statement fraud in the American firms decreases with the percentage of outside directors. Peasnell et al. (2000) and Klein (2002) revealed that the independent board mitigates earnings management. In the same context, Bushman et al. (2004), Vafeas (2005) and Karamanou and Vafeas (2005) advanced that the information quality increases with the percentage of outside directors. Similarly, Beekes et al. (2004) noticed that the board independence allows disclosing information of good quality by the firms in the United Kingdom. In other contexts, Firth et al. (2007) indicated that the presence of independent directors improves the earnings quality of Chinese firms. Dimitropoulos and Asteriou (2010) confirmed this finding for a sample of Greek firms. In contrast, other studies suggested that the independent directors are not enough competent to control the managers and their presence in the board has no effect on the reporting quality [Petra (2007) for American firms, Bradbury et al. (2006) for Singapore and Malaysian firms and Ahmed et al. (2006) for New Zealand firms].

Second, several authors underlined that the size of the board of directors can be associated with a good quality of financial reporting. A reduced number of directors implies a high degree of coordination and communication between them and the managers (Jensen, 1993). Indeed, Vafeas (2000), Ahmed et al. (2006) and Bradbury et al. (2006) found that large board size reduces the information content of incomes and intensifies the earnings management respectively for American, Singapore and New Zealand firms. However, several authors argued that the high number of directors ensures the value relevance of financial statements (Byard et al., 2006), while others did not confirm this link (Firth et al., 2007).

Third, the corporate governance literature has emphasized the need to separate the positions of CEO (chief executive officer) and board chairman to guarantee the board independence and improve the firm transparency (Jensen, 1993). In this respect, Dechow et al. (1996) revealed that the duality CEO-chairman increases the likelihood of violating the accounting principles in American firms. Byard et al. (2006) indicated that the presence of a CEO who serves also as the board chairman is associated with poor quality of financial information. Similarly, Beekes et al. (2004) and Firth et al. (2007) reported that the financial reporting is more relevant in the case of separating the positions of CEO and board chairman for British and Chinese firms. Nevertheless, other authors did not detect a significant association between CEO duality and information quality in various contexts of studies (Ahmed et al., 2006; Bradbury et al., 2006; Petra 2007).

Besides, the external audit can be an effective control mechanism to monitor the managers and guarantee the integrity of financial reports (Jensen and Meckling, 1976; Watts and Zimmerman, 1983). The appointment of an independent external auditor can reduce the probability of earnings manipulation by lessening the managerial 
opportunism (DeAngelo, 1981; Becker et al., 1998; Chung et al., 2003). In practice, the auditor reputation or quality is apprehended by his belonging to the major audit firms named BIG 4 (Brown et al., 2010). Several authors advocated that the financial information is more reliable for BIG 4 clients in comparison with other companies (Teoh and Wong, 1993; Becker et al., 1998). (Note 1)

Furthermore, the theoretical and empirical studies about corporate governance have suggested that the ownership structure can affect the financial reporting quality (Fan and Wong, 2002). On the one hand, the presence of blockholders may curb the discretionary behavior of the managers, incite them to adopt profitable strategies and disclose relevant and reliable information (Demsetz and Lehn, 1985; Shleifer and Vishny 1986). Indeed, Jiambalvo et al. (2002), Klein (2002) and De Bos and Donker (2004) reported that the ownership concentration reduces the earnings management in the American firms which improves the financial disclosure quality. Similarly, Han (2005), Karamanou and Vafeas (2005) and Wang (2006) argued that the concentrated ownership decreases the level of discretionary accruals and increases the voluntary disclosures made by managers. These findings have been also proven in other contexts of studies such as the British firms (Beekes et al., 2004) and the Singapore firms (Yeo et al., 2002).

On the other hand, the presence of controlling shareholders may exacerbate the agency problems (Fan and Wong, 2002). Holding a large fraction of capital incites shareholders to be entrenched in the firm and to expropriate the other shareholders (Morck et al., 1988). In this respect, many studies advanced that concentrated ownership reduces the relevance of the financial information. Donnelly and Lynch (2002) showed that the earnings quality is weak for British firms that are characterized by ownership concentration. In the Asian context, Fan and Wong (2002) and Bradbury et al. (2006) detected that the presence of blockholders alters the credibility of the accounting numbers. Similarly, Firth et al. (2007) discerned that the presence of the major shareholders who may be financial or state institutions and foreigners entails poor quality of financial information. Nevertheless, other authors such as Byard et al. (2006) and Ballesta and Meca (2007) did not confirm the link between the ownership structure and the quality of financial reporting in different countries.

\section{Methodological approach}

To investigate the impact of the governance mechanisms on the financial reporting quality, we use a sample of 22 non financial firms listed on the Tunis Stock Exchange during the period 1997-2007. We exclude financial firms because they have distinctive features compared to non-financial companies. In what follows, we discuss the study variables, the regression model and the hypotheses.

In the first step, we measure the financial information quality using two models. The first one is the McNichols (2002) model which considers the standard deviation of the residuals or the error terms as a measure of reporting quality. Large values of the model residuals mean a considerable level of discretionary accruals and so a poor quality of the financial information. The model equation is as follows:

$$
\frac{A C C R_{i t}}{T A_{i t-1}}=\frac{\alpha_{0}}{T A_{i t-1}}+\frac{\alpha_{1} C F_{i t-1}}{T A_{i t-1}}+\frac{\alpha_{2} C F_{i t}}{T A_{i t-1}}+\frac{\alpha_{3} C F_{i t+1}}{T A_{i t-1}}+\frac{\alpha_{4} \Delta R E V_{i t}}{T A_{i t-1}}+\frac{\alpha_{5} P P E_{i t}}{T A_{i t-1}}+\varepsilon_{i t}
$$

Where $\mathrm{ACCR}_{\mathrm{it}}$ : the total current accruals, $\mathrm{CF}_{\mathrm{it}}$ : the operating cash flows of the current period, $\mathrm{CF}_{\mathrm{it}-1}$ : the operating cash flows of the previous period, $\mathrm{CF}_{\mathrm{it}+1}$ : the operating cash flows of the next period, $\triangle \mathrm{REV}_{\mathrm{it}}$ : the change in revenues and $\mathrm{PPE}_{\mathrm{it}}$ : the level of property, plant and equipment. All these variables are scaled by lagged total assets $\left(\mathrm{TA}_{\mathrm{it}-1}\right)$. (Note 2)

The second model captures the information content of earnings (Ball and Brown, 1968; Collins and Kothari, 1989). If the accounting incomes are informative, the stock returns will incorporate all the available information which indicates a good quality of financial reporting (Ashbaugh et al., 2006). Hence, a high level of the standard deviation of the residuals entails a poor quality of information. The model equation is as follows:

$$
R E T_{i t}=\alpha_{0}+\alpha_{1} E A R N_{i t}+\alpha_{2} \Delta E A R N_{i t}+\alpha_{3} N E G_{i t}+\alpha_{4} E A R N_{i t} * N E G_{i t}+\varepsilon_{i t}
$$

Where $\mathrm{RET}_{\mathrm{it}}$ : the annual stock returns of the current year, $\mathrm{EARN}_{\mathrm{it}}$ : the net income per share of the current year, $\triangle E A R N_{i t}$ : the variation of earnings per share between year ' $t-1$ ' and year ' $t$ ', $N^{\prime} G_{i t}$ ' a binary variable equal to 1 if the firm makes a loss and 0 otherwise and $\mathrm{EARN}_{\mathrm{it}}{ }^{*} \mathrm{NEG}_{\mathrm{it}}$ : the interaction between the earnings per share and their sign.

In order to better evaluate the reporting quality of our sample, we use a principal component analysis. We obtain a single axis that we call "REPQUAL" which includes an accounting (discretionary accruals) and a market based (informativeness of earnings) measures of the financial information. A high value of this factor implies a poor reporting quality. 
In the second step, we identify the corporate governance features of the Tunisian firms. We consider several variables that are related to the board of directors (composition, size and CEO duality), the reputation of the external auditor and the ownership structure (ownership concentration and identity of shareholders). To the best of our knowledge, the identity of the directors or the shareholders and its impact on the financial reporting quality were not heavily discussed by prior research especially in the emerging markets (Firth et al., 2007). This constitutes principally the contribution of this paper compared to prior studies. In the Tunisian context, the board usually contains other types of directors (in addition to outside members) who represent the major shareholders, the families, the State, the financial institutions and the foreigners. The presence of these directors can be seen as an effective governance mechanism since they can monitor the managers and incite them to improve the financial reporting quality. However, they may have incentives to take advantage of asymmetric information, especially when they hold a large fraction of the shares which may alter the information quality. Thus, we include in our study the identity of the directors. (Note 3)

Similarly, we notice that the major shareholders of the Tunisian firms are the State, the families, the institutional investors and the foreigners. Their presence may be associated with a robust control of the management team and a good quality of financial disclosure (Xu and Wang, 1999; Rajgopal et al., 2002). They also may be entrenched in the firm and expropriate minority shareholders which consequently alters the reporting quality (Chen et al., 2003). We include in our study, the Herfindahl index as a measure of ownership concentration and the shareholding of the foreigners, the financial institutions, the families and the State (see Table 1 for the definition of all variables).

Therefore, we obtain a large number of governance variables that we synthesize, using a principal component analysis, in four factorial axes. These factors represent the main mechanisms of control which are specific to the Tunisian firms. The first factorial axis is associated with the percentage of foreign directors and shareholders, the separation of the CEO and chairman positions and the presence of outside directors. It reflects the power of the foreigners that we call "FOREIG". The second factor is related to the ownership concentration and represents the intensity of control in a firm that we call "BLOCK". The third factor is correlated to the percentage of directors who represent families and their shareholding. It reflects the power of the families and is named "FAMIL". The fourth axis is associated with the percentage of directors who represent the State and the financial institutions and their shareholding. It corresponds to the power of the State and the institutional investors and is called "STAFIN".

In the third step, we use the following regression model to examine the impact of the governance mechanisms (the four factors) on the financial information quality of the Tunisian firms:

$$
\text { REPQUAL }_{i t}=\alpha_{0}+\alpha_{1} \text { FOREIG }_{i t}+\alpha_{2} \text { BLOCK }_{i t}+\alpha_{3} \text { FAMIL }_{i t}+\alpha_{4} \text { STAFIN }_{i t}+\alpha_{5} M \text { TB }_{i t}+\alpha_{6} L E V_{i t}+\alpha_{7} S_{Z I Z E_{i t}}+\varepsilon_{i t}
$$

According to previous research, we include control variables that can influence the financial reporting quality, such as the firm size, the debt ratio and the growth opportunities (Bradbury et al., 2006; Firth et al., 2007). The firm size (SIZE) is the natural logarithm of the total assets. The firm's debt (LEV) is measured by the ratio of the total debts to its total assets. The growth opportunities (MTB) are defined by the Market-to-Book ratio which is the market value of the equity divided by its book value.

Hence, we aim in our study to test the following hypotheses:

\section{H 1: The control by the foreigners affects the quality of financial reporting.}

\section{H 2: The control by the blockholders affects the quality of financial reporting.}

$H$ 3: The control by the families affects the quality of financial reporting.

\section{$H$ 4: The control by the State and the financial institutions affects the quality of financial reporting.}

\section{Study results}

In Table 2, we discuss the governance features of our sample. In general, we find that the Tunisian firms are characterized by the large size of the board ( 9 directors on average), the low proportion of outside directors (the average percentage is $8.1 \%$ ), the CEO duality (there is a separation of the CEO and chairman positions in only $24 \%$ of the cases) and the average use of the BIG 4 auditors (only $40 \%$ of the firms have a BIG 4 audit firm). Besides, we perceive that the board of directors is mainly composed of members who represent the State, the families, the foreigners and the financial institutions (the average percentage of them is $36 \%, 33 \%, 25 \%$ and $10.5 \%$ respectively).

Moreover, we notice that the Tunisian firms are characterized by a high level of ownership concentration. The major shareholders hold on average $70 \%$ of the capital and the Herfindhal index is equal to $38 \%$ on average. (Note 4 ) The State, the families, the institutional investors and the foreigners hold on average $37 \%, 34 \%, 25 \%$ and $20 \%$ of the firm's capital respectively. These findings denote that the board independence may be altered in the Tunisian context due to the concentrated ownership. Like most firms in emerging markets, the Tunisian companies are small 
and medium enterprises and the majority of them are family businesses or state-owned enterprises. The high financing by bank loans increases the presence of the creditors on the board of directors as well as their shareholding in the firms. This constitutes a response to guarantee the repayment of the granted loans. We also notice that the Tunisian financial market is attracting the foreign investors following its international opening. This will incite firms to improve the financial reporting quality and to get more foreign financing.

Next, we check if there is a multicollinearity problem among the explanatory variables of our model. According to the VIF test (variance inflation factors), we conclude that this problem does not arise (all factors are below 2). Then, we proceed to the specification of our model based on panel data tests. We detect the presence of individual fixed effects and the heteroscedasticity among the variables, that's why we estimate our model using the generalized least-squares method. (Note 5)

The results of our study are reported in Table 3. On the whole, we find that the governance mechanisms have a significant effect on the financial reporting quality of the Tunisian firms. Specifically, the control by the foreigners is positively associated with the factor representing the information quality. In other words, their presence in the Tunisian firms involves a poor quality of financial disclosure. This suggests that the foreign shareholders and directors are related to the managers, which facilitates their entrenchment and the pursuit of individual goals. Consequently, the Tunisian investors do not rely on the control by the foreign investors. Also, they are not reassured by the board independence given the limited number of the outside directors and the high frequency of CEO duality. This finding is consistent with the study of Firth et al. (2007) in the Chinese context.

Besides, we discern that the ownership concentration is negatively associated with the financial reporting quality. This can be explained by the fact that the major shareholders are entrenched in the Tunisian companies. Therefore, they can expropriate the firm resources due to their power, which increases the earnings management and the information asymmetry. This result was confirmed by several studies in other contexts such as Fan and Wong (2002) in the Asian context, Bradbury et al. (2006) in Singapore and Malaysia and Firth et al. (2007) in China.

Similarly, we perceive that the power of families reduces the quality of financial information of our sample. In fact, several Tunisian companies are controlled by the families who aim to protect and safeguard their wealth since their portfolio is not diversified among several firms. They can develop a network of relationships with the management team in order to pursue their personal goals and make decisions in their own self interest. Thus, the families seem to be entrenched in the Tunisian firms and they can possibly expropriate minority shareholders. This result was proved by Wang (2006) for the American firms.

In contrast, we find that the power of the State and the financial institutions has a positive and significant effect on the quality of reporting. Indeed, the State and the institutional investors are the major shareholders of the Tunisian firms and they are present in a considerable way on their board of directors. Such is the case, they ensure the control of management and require informative disclosure. Therefore, their power is associated with good quality of reporting, which reduces the earnings manipulation and improves the information content of accounting incomes. This finding is consistent with the study of Firth et al. (2007) for Chinese firms and Han (2005) for American firms.

Finally, we notice that the firm size and the growth opportunities are associated with a poor quality of financial information. This can be explained by the fact that the firm size increases its operating risk which leads the managers to exercise accounting discretion in order to mislead the investors. Also, the high-growth firms present important potential investments that incite the managers to manipulate earnings to obtain better financing terms (Ballesta and Meca, 2007). However, we observe that the debt ratio improves the information quality of the Tunisian companies. This can be due to the fact that the creditors require a good quality of financial reporting in order to grant credits to the firms and guarantee the repayment of the debts.

\section{Conclusion}

This study evaluates the effect of governance mechanisms on financial information quality for a sample of Tunisian non financial companies listed on the Tunis Stock Exchange, during the period 1997-2007. The results show that the Tunisian firms are characterized by the lack of the board independence and the high level of the ownership concentration. The governance mechanisms are represented mainly by the power of the foreigners, the families, the blockholders, the institutional investors and the State. These mechanisms of control affect the financial reporting quality of the Tunisian companies. On the one hand, the presence of foreigners, families and major shareholders is associated with poor accounting quality which underlines that they are entrenched in the Tunisian firms. Consequently, their power increases the information uncertainty which constitutes an information risk that may eventually affect the cost of capital of the firms (Easley and O'Hara, 2004; Leuz and Verrecchia, 2005). This question is not treated in our study and can be an opportunity for future research. On the other hand, the power of the State and the institutional investors improves the financial reporting quality. This suggests that the control by the 
State and the financial institutions is an effective governance mechanism to constrain the opportunistic behavior of the Tunisian firms' managers and enhance the transparency and the relevance of the financial reporting.

Overall, our study supports the argument that the corporate governance affects the accounting quality in the Tunisian context. However, further research is necessary to provide additional insight into the role of corporate governance and the reporting quality in the Tunisian firms. First, it would be appropriate to verify these findings by including the financial companies such as the banks. Then, it would be worthwhile to incorporate other governance variables (such as the managerial ownership) or other measures of information quality (such as the voluntary disclosure). It would be also very interesting to determine if the governance mechanisms and the reporting quality influence the cost of capital of the Tunisian firms. Finally, we suggest investigating the link between corporate governance and accounting quality in other emerging markets.

\section{Acknowledgment}

We are so thankful to Ms Souad Seboui Associate Professor of Finance (Ecole Supérieure des Sciences Economiques et Commerciales de Tunis, University of Tunis, Tunisia) for its valuable comments.

\section{References}

Agrawal, A. \& Chadha, S. (2005). Corporate Governance and Accounting Scandals. Journal of Law and Economics, $48,(2), 371-406$.

Ahmed, K., Hossain, M. \& Adams, M. (2006). The Effects of Board Composition and Board Size on the Informativeness of Annual Accounting Earnings. Corporate Governance: An International Review, 14, (5), 418-431.

Ashbaugh, H., Collins, D. \& LaFond, R. (2006). The Effects of Corporate Governance on Firms' Credit Ratings. Journal of Accounting and Economics, 42, 203-243.

Ball, R. \& Brown, P. (1968). An Empirical Evaluation of Accounting Income Numbers. Journal of Accounting Research, 6, (2), 159-178.

Ballesta, P. \& Meca, E. (2007). Ownership Structure, Discretionary Accruals and the Informativeness of Earnings. Corporate Governance, 15, (4), 677-691.

Beasley, M. (1996). An Empirical Analysis of the Relation between the Board of Director Composition and Financial Statement Fraud. The Accounting Review, 71, 443-465.

Becker, C., DeFond, M., Jiambalvo, J. \& Subramanyam, K. (1998). The Effect of Audit Quality on Earnings Management. Contemporary Accounting Research, 15, 1-24.

Beekes, W. \& Brown, P. (2006). Better-Governed Australian Firms Make More Informative Disclosures. Journal of Business Finance and Accounting, 33, (3), 422-450.

Beekes, W., Pope, P. \& Young, S. (2004). The Link between Earnings and Timeliness, Earnings Conservatism and Board Composition: Evidence from the UK. Corporate Governance: An International Review, 12, 14-59.

Bradbury, M., Mak, Y. \& Tan, S. (2006). Board characteristics, audit committee characteristics and abnormal accruals. Pacific Accounting Review, 18, 47-68.

Brown, J., Falaschetti, D. \& Orlando, M. (2010). Auditor Independence and Earnings Quality: Evidence for Market Discipline vs. Sarbanes-Oxley Proscriptions. American Law and Economics Review, 12, (1), 39-68.

Brown, L. \& Caylor, M. (2006). Corporate Governance and Firm Valuation. Journal of Accounting and Public Policy, 25, (4), 409-434.

Bushman, R. \& Smith, A. (2001). Financial Accounting Information and Corporate Governance. Journal of Accounting and Economics, 32, 237-351.

Bushman, R. \& Smith, A. (2003). Transparency, Financial Accounting Information, and Corporate Governance. Economic Policy Review, 9, (1), 65-87.

Bushman, R., Chen, Q., Engel, E. \& Smith, A. (2004). Financial Accounting Information, Organizational Complexity and Corporate Governance Systems. Journal of Accounting and Economics, 37, (2), 167-201.

Byard, D., Li, Y. \& Weintrop, J. (2006). Corporate Governance and the Quality of Financial Analyst's Information. Journal of Accounting and Public Policy, 25, 609-625.

Chung, R., Firth, M. \& Kim, J. (2003). Auditor Conservatism and Reported Earnings. Accounting Business Research, 33, 19-32. 
Collins, D. \& Kothari, S. (1989). An Analysis of Intertemporal and Cross-Sectional Determinants of Earnings Response Coefficients. Journal of Accounting and Economics, 11, 143-181.

De Bos, A. \& Donker, H. (2004). Monitoring Accounting Changes: Empirical Evidence from the Netherlands. Corporate Governance: An International Review, 12, 60-73.

DeAngelo, L. (1981). Auditor Size and Audit Quality. Journal of Accounting and Economics, 3, 183-199.

Dechow, P., Sloan, R. \& Sweeney, A. (1996). Causes and Consequences of Earnings Manipulation: An Analysis of Firms Subject to Enforcement Actions by the SEC. Contemporary Accounting Research, 13, (1), 1-36.

Demsetz, H. \& Lehn, K. (1985). The Structure of Corporate Ownership: Causes and Consequences. Journal of Political Economy, 33, 3-53.

Dimitropoulos, P. \& Asteriou, D. (2010). The Effect of Board Composition on the Informativeness and Quality of Annual Earnings: Empirical Evidence from Greece, Research in International Business and Finance, 24, 190-205.

Donnelly, R. \& Lynch, C. (2002). The Ownership Structure of UK Firms and the Informativeness of Accounting Earnings. Accounting and Business Research, 32, 245-257.

Easley, D. \& O'Hara, M. (2004). Information and the Cost of Capital. Journal of Finance, 59, 1553-1683.

Fan, J. \& Wong, J. (2002). Corporate Ownership Structure and the Informativeness of Accounting Earnings in East Asia. Journal of Accounting and Economics, 33, 401-425.

Firth, M., Fung, P. \& Rui, O. (2007). Ownership, two-tier Board Structure, and the Informativeness of Earnings: Evidence from China. Journal of Accounting and Public Policy, 26, (4), 463-496.

Han, S. (2005). Ownership Structure and Quality of Financial Reporting. Working Paper of University of Illinois.

Jensen, M. \& Meckling, W. (1976). Theory of the Firm: Managerial Behavior, Agency Costs, and Ownership Structure. Journal of Financial Economics, 3, (4), 305-360.

Jensen, M. (1993). The Modern Industrial Revolution, Exit, and the Failure of Internal Control Systems. The Journal of Finance, 25, (3), 831-873.

Jiambalvo, J., Rajgopal, S. \& Venkatachalam, M. (2002). Institutional Ownership and the Extent to Which Stock Prices Reflect Future Earnings. Contemporary Accounting Research, 19, (1), 117-145.

Karamanou, I. \& Vafeas, N. (2005). The Association between Corporate Boards, Audit Committees, and Management Earnings Forecasts: An Empirical Analysis. Journal of Accounting Research, 43, (3), 453- 486.

Klein, A. (2002). Audit Committee, Board of Director Characteristics and Earnings Management. Journal of Accounting and Economics, 33, 375-400.

Leuz, C. \& Verrecchia, R. (2005). Firms' Capital Allocation Choices, Information Quality, and the Cost of Capital. Working paper, University of Pennsylvania.

McNichols, F. (2002). Discussion of the Quality of Accruals and Earnings: The Role of Accrual Estimation Errors. The Accounting Review, 77, 61-69.

Morck, R., Shleifer, A. \& Vishny, R. (1988). Management Ownership and Market Valuation. Journal of Financial Economics, 20, 293-315.

Peasnell, K., Pope, P. \& Young, S. (2000). Accrual Management to Meet Earnings Targets: UK Evidence Pre- and Post-Cadbury. British Accounting Review, 32, 415-445.

Petra, S. (2007). The Effects of Corporate Governance on the Informativeness of Earnings. Economics of Governance, 8, 129-152.

Rajgopal, S., Venkatachalam, M. \& Jiambalvo, J. (2002). Institutional Ownership and the Extent to Which Stock Prices Reflect Future Earnings. Contemporary Accounting Research, 19, 117-146.

Shleifer, A. \& Vishny, R. (1986). Large Shareholders and Corporate Control. Journal of Political Economy, 95, 461-488.

Teoh, S. \& Wong T. (1993). Perceived Auditor Quality and the Earnings Response Coefficients. The Accounting Review, 68, 346-367.

Vafeas, N. (2000). Board Structure and the Informativeness of Earnings. Journal of Accounting and Public Policy, $19,139-160$. 
Vafeas, N. (2005). Audit Committees, Boards and the Quality of Reported Earnings. Contemporary Accounting Research, 22, 1093-1122.

Wang, D. (2006). Founding Family Ownership and Earnings Quality. Journal of Accounting Research, 44, (3), 619656.

Watts, R. \& Zimmerman, J. (1983). Agency Problems, Auditing and the Theory of the Firm: Some Evidence. Journal of Law and Economics, 26, 613-634.

Xu, X. \& Wang, Y. (1999). Ownership Structure and Corporate Governance in Chinese Stock Companies. China Economic Review, 10, 75-89.

Yeo, G., Tan, P. \& Chen, S. (2002). Corporate Ownership Structure and the Informativeness of Earnings. Journal of Business Finance and Accounting, 29, (7), 1023-1046.

\section{Notes}

Note 1. Since 2002, the large audit firms are called BIG 4 and are Deloitte, Ernst \& Young, PricewaterhouseCoopers and KPMG.

Note 2. The total accruals are defined as the net income before extraordinary items minus the cash flow from operations.

Note 3. See Table 1 for variables name and definition.

Note 4 . The percentage of major shareholders who control $10 \%$ or more of the firm shares is $70 \%$ on average. In the principal component analysis, we introduce only the Herfindahl index as a measure of the ownership concentration of our sample.

Note 5. The test of individual effects and the Hausman test are both significant at the $1 \%$ level. The results confirm that the individual effects are fixed. In addition, the Wald test for heteroscedasticity is significant at the $1 \%$ level which proves the presence of heteroscedasticity problem in our data and justifies the use of the generalized least-squares method.

Table 1. Governance variable definitions

\begin{tabular}{|c|l|}
\hline Variable & \multicolumn{1}{|c|}{ Definition } \\
\hline SIZBOAD & The total number of the directors. \\
\hline NONDUAL & $\begin{array}{l}\text { The non duality is a dummy variable that takes 1 when there is a separation of the positions of } \\
\text { CEO and board chairman and zero if not. }\end{array}$ \\
\hline BIG 4 & The auditor quality is a dummy variable that equals 1 if the auditor is a BIG 4 and zero otherwise. \\
\hline DIRIND & The percentage of outside directors to total board size. \\
\hline DIRSTAT & The percentage of directors who represent the State. \\
\hline DIRFAM & The percentage of directors who represent the families. \\
\hline DIRFIN & The proportion of directors who represent the financial institutions. \\
\hline DIRFOR & The proportion of directors who represent the foreigners. \\
\hline HERFINDAHL & $\begin{array}{l}\text { The Herfindahl index is the sum of the squares of the percentage shareholdings of the three largest } \\
\text { shareholders. }\end{array}$ \\
\hline MAJ 10 & The percentage of shares owned by all shareholders with more than 10\% stake in the firm. \\
\hline OWNSTAT & The percentage of capital owned by the State. \\
\hline OWNFAM & The percentage of capital owned by the families. \\
\hline OWNFIN & The percentage of capital held by the financial institutions. \\
\hline OWNFOR & The percentage of capital held by the foreign shareholders. \\
\hline
\end{tabular}


Table 2. Descriptive statistics

\begin{tabular}{|c|c|c|c|c|}
\hline Variable & Mean & SD & Max & Min \\
\hline NONDUAL* & 0,244 & - & - & - \\
\hline BIG 4* & 0,408 & - & - & - \\
\hline SIZBOAD & 9,156 & 1,871 & 12 & 5 \\
\hline DIRIND & 0,081 & 0,129 & 0,625 & 0 \\
\hline DIRSTAT & 0,362 & 0,337 & 0,916 & 0 \\
\hline DIRFAM & 0,331 & 0,339 & 1 & 0 \\
\hline DIRFIN & 0,255 & 0,190 & 0,714 & 0 \\
\hline DIRFOR & 0,105 & 0,149 & 0,5 & 0 \\
\hline HERFINDAHL & 0,383 & 0,214 & 1 & 0,04 \\
\hline MAJ 10 & 0,701 & 0,147 & 1 & 0,200 \\
\hline OWNSTAT & 0,372 & 0,276 & 1 & 0 \\
\hline OWNFAM & 0,340 & 0,307 & 0,991 & 0 \\
\hline OWNFIN & 0,257 & 0,225 & 0,907 & 0 \\
\hline OWNFOR & 0,203 & 0,207 & 0,796 & 0 \\
\hline MTB & 1,959 & 1,848 & 12,583 & 0,212 \\
\hline SIZE & 17,743 & 0,924 & 21,112 & 16,148 \\
\hline LEV & 0,477 & 0,216 & 1,356 & 0,043 \\
\hline *Frequency of the variable. & \multicolumn{5}{|l}{} \\
\hline
\end{tabular}

Where,

NONDUAL: the non duality is a dummy variable that takes 1 if there is a separation of CEO and chairman positions and zero if not. BIG 4: the auditor quality is a dummy variable that equals 1 if the auditor is a BIG 4 and zero otherwise.

SIZBOAD: the total number of the directors.

DIRIND: the percentage of outside directors.

DIRSTAT: the percentage of directors who represent the State.

DIRFAM: the percentage of directors who represent the families.

DIRFIN: the proportion of directors who represent the financial institutions.

DIRFOR: the proportion of directors who represent the foreigners.

HERFINDAHL: the Herfindahl index is the sum of the squares of the percentage shareholdings of the three largest shareholders.

MAJ 10: the percentage of shares held by the shareholders with more than $10 \%$ stake in the firm.

OWNSTAT: the percentage of capital owned by the State.

OWNFAM: the percentage of capital owned by the families.

OWNFIN: the percentage of capital held by the financial institutions.

OWNFOR: the percentage of capital held by the foreign shareholders.

MTB: the Market-to-Book ratio is the market value of equity divided by its book value.

SIZE: the firm size is the natural logarithm of total assets.

LEV: the firm leverage is the total debts divided by total assets.

Table 3. Results of the regression

\begin{tabular}{|c|c|c|c|}
\hline Variable & Coefficient & Z-Statistic & P-value \\
\hline FOREIG & 0.099 & 2.41 & 0.016 \\
\hline BLOCK & 0.206 & 6.07 & 0.000 \\
\hline FAML & 0.338 & 8.19 & 0.000 \\
\hline STAFIN & -0.119 & -2.08 & 0.038 \\
\hline MTB & 0.101 & 6.42 & 0.000 \\
\hline LEV & -0.525 & -5.72 & 0.000 \\
\hline SIZE & 0.138 & 4.44 & 0.000 \\
\hline
\end{tabular}

Where,

FOREIG: the control by the foreign directors and shareholders.

BLOCK: the ownership concentration and the control by the major shareholders.

FAML: the control by the families and the directors who represent them on the board.

STAFIN: the control by the State and the financial institutions.

MTB: the Market-to-Book ratio.

LEV: the firm leverage.

SIZE: the firm size. 